\title{
Character association and path analysis studies in brinjal (Solanum melongena L.) genotypes
}

\author{
Vittal Mangi", H. B. Patil, Sanganamoni Mallesh, Shivappa M karadi and D. Satish \\ Department of Vegetable Science, College of Horticulture, University of Horticultural Sciences, Bagalkot-587104 \\ (Karnataka), INDIA \\ *Corresponding author. E-mail: vittalmangiphd@gmail.com \\ Received: February 20, 2016; Revised received: October 22, 2016; Accepted: January 3, 2017
}

\begin{abstract}
Character association and path analysis in sixty genotypes of brinjal was studied for 17 important characters. The character association studies revealed that the total yield per plant had significant and positive association with plant height (0.385), plant spread (0.660), number of primary branches (0.545), stem girth (0.539) at 90 days after transplanting (DAT), early yield per plant, number of fruits per plant and fruit diameter. While it was negatively and significantly associated with days to first flowering $(-0.302$ and -0.230$)$, days to 50 per cent flowering $(-0.272$ and $0.229)$ and days to first fruit maturity $(-0.164$ and -0.168$)$ at both genotypic and phenotypic level. Narrow differences between the genotypic and phenotypic correlation coefficients were observed for various traits in the present findings. This indicates the lesser influence of the environment in the expression of these traits and presence of strong inherent association among the traits. Path analysis studies revealed that significant positive association at genotypic level among the traits viz., plant height (0.235), leaf area (at 90 DAT) (0.228), days to first fruit maturity (0.162), number of fruits per cluster (0.280) and early yield per plant (1.903) had exhibited true association with direct effect on yield per plant. The direct selection for these traits would be rewarding for improvement in the total yield per plant.
\end{abstract}

Keywords: Brinjal, Character association, Genotypes, Path analysis

\section{INTRODUCTION}

Brinjal (Solanum melongena L.) is an important and popular vegetable crop of India and it belongs to the family Solanaceae. Brinjal is mainly self pollinated, but a certain percentage of cross pollination also occurs. The immature fruit is primarily used as cooked vegetable and utilized in the preparation of various dishes like sliced bhaji, stuffed curry, bertha, chutney, vangibath and pickles in different parts of the world. Brinjal fruits and are ranked amongst the top ten vegetables in terms of antioxidant capacity due to the fruit phenols and flovonoic constituents (Singh et al., 2009), which have been linked to various health benefits (Hung et al., 2004).

A study of correlation between different quantitative characters provides an idea of association. It could be effectively exploited to formulate selection strategies for improving yield and quality. Association of characters like yield, its components, and other economical traits is important for making selection in the breeding programme. It suggests the advantage of a scheme of selection for more than one character at a time (Kalloo. 1994). Further in order to have clearer picture of yield components for effective selection progamme, it would be desirable to consider the relative magnitude of association of various characters with yield.
The path coefficient technique helps in estimating direct and indirect contribution of various components in building up the total correlation towards yield. On the basis of these studies, the quantum importance of individual character will facilitate the selection programme for better gains. Path analysis also measures the relative importance of causal factors involved. This is simply a standardized partial regression analysis, where in total correlation values were subdivided into causal factors (Shipley, 2000). Keeping this in view, the present investigation was aimed at assessing the association of various characters and direct and indirect path effects of fifteen independent components on fruit yield in sixty genotypes.

\section{MATERIAL AND METHODS}

The experiment was conducted at the Research Block of Vegetable Section in Sector No. 1 under the University of Horticultural Sciences, Bagalkot (Karnataka) during the year 2013-14. Sixty genotypes of brinjal were grown in randomized block design with three replications. Ridges and furrows prepared at a spacing of $75 \mathrm{~cm}$. On these ridges six week old seedlings were planted at a spacing of $60 \mathrm{~cm}$ (Anon., 2012). Thus, 15 plants were planted on each ridge with plot area of $6.75 \mathrm{~m}^{2}$. Five randomly chosen plants in each replication of each entry were labelled and used for recording 
the observations for the growth parameters viz., plant height $(\mathrm{cm})$, plant spread $(\mathrm{cm})$, number of primary branches per plant, stem girth $(\mathrm{cm})$ and leaf area $\left(\mathrm{cm}^{2}\right)$ at 90 days after transplanting. Earliness parameters $v i z$., days to first flowering, days to 50 per cent flowering and days to first fruit maturity and yield parameters $v i z$, fruit length $(\mathrm{cm})$, fruit diameter $(\mathrm{cm})$, fruit lengthdiameter ratio, average fruit weight $(\mathrm{g})$, number of fruits per cluster, number of fruits per plant, early yield per plant (first three pickings-kg) and total yield per plant $(\mathrm{kg})$ were recorded. Data on qualitative characters were also recorded. Per cent dry matter in fruit was found by drying the cut fruit samples in hot air oven at $60^{\circ} \mathrm{C}$ till constant weight of samples was achieved over the two subsequent observations and dry weight of fruits was recorded and per cent dry matter in fruit was worked. The correlation co-efficient among all important character combinations at phenotypic $\left(r_{p}\right)$ and genotypic $\left(r_{g}\right)$ level were estimated by employing formula given by Al-Jibourie et al. (1958).

\section{RESULTS AND DISCUSSION}

Correlation studies: Genetic variability studies provide information on the extent of improvement could be achieved in different characters, but they do not focus on the extent and nature of relationship existing between various characters. Therefore, for rational approach towards the improvement of yield, selection has to be made for the yield contributing characters, since there may not be genes for yield per plant, but only for various yield components (Grafius, 1959). Further, many of these yield contributing characters may interact in desirable and undesirable direction. Hence, a knowledge regarding the association of various characters among themselves and with economic characters is essential. In the present study, the genotypic and phenotypic correlation coefficients were worked out for growth, earliness, yield and quality components in brinjal. The difference between the genotypic and phenotypic correlation coefficients was narrow for various traits in the present findings and this indicates the lesser influence of environment in the expression of these traits and presence of strong inherent association among the traits.

Genotypic and phenotypic correlations are presented in Tables 1 and 2. Total yield per plant was found to be positively and significantly (at $\mathrm{p}=0.01$ ) associated with plant height at 90 days after transplanting $\left(r_{\mathrm{g}}=0.385\right.$ and $\left.r_{p}=0.333\right)$, plant spread at 90 DAT $\left(r_{g}=0.660\right.$ and $\left.r_{p}=0.454\right)$, number of primary branches at 90 DAT $\left(r_{g}=0.545\right.$ and $\left.r_{p}=0.470\right)$, stem girth at 90 DAT $\left(r_{g}=\right.$ 0.539 and $\left.r_{p}=0.420\right)$, fruit diameter $\left(r_{g}=0.242\right.$ and $r_{p}=$ $0.224)$, early yield per plant $\left(r_{g}=1.000\right.$ and $\left.r_{p}=0.896\right)$ and number of fruits per plant $\left(r_{g}=0.449\right.$ and $r_{p}=$ 0.499). Several workers was supported earlier that total yield per plant positively and significantly correlated with number of primary branches, number of fruits per plant by Kalpana et al. (2010), Dahatonde et al. (2010), Karak et al. (2012), Thangamani and Jansirani (2012), Arunkumar et al. (2013), Nayak and Nagre (2013), Shende et al. (2014) and Patel et al. (2015). Total yield per plant can be improved by imposing simultaneous selection for these characters. But it was negatively and significantly (at $\mathrm{p}=0.01$ ) associated with days to first flowering $\left(r_{g}=-0.302\right.$ and $\left.r_{p}=-0.230\right)$, days to 50 per cent flowering $\left(r_{g}=-0.272\right.$ and $r_{p}=-$ 0.229) (Muniappan et al., 2010, Thangamani and Jansirani, 2012 and Patel et al., 2015) and days to first fruit maturity at $\mathrm{p}=0.05\left(\mathrm{r}_{\mathrm{g}}=-0.164\right.$ and $\left.\mathrm{r}_{\mathrm{p}}=-0.168\right)$ both at genotypic and phenotypic level. Hence, these characters are considered least for simultaneous improvement of yield.

Path co-efficient analysis: Though correlation analysis indicates the association pattern of component traits with yield, it simply represents the overall association of a particular trait with yield rather than providing cause and effect relationship. The technique of path coefficient analysis developed by Wright (1921) and demonstrated by Dewey and Lu (1957) facilitates in splitting the correlation coefficients into the measures of direct and indirect effects. It is a standardised by partial regression coefficient analysis. As such, it measures the direct influence of one variable upon other. Such information would be of great value in enabling the breeder to specifically identify important component traits of yield and utilise the genetic stock for improvement in a planned way.

There are 17 important growth, earliness, yield and quality parameters subjected to genotypic and phenotypic path coefficient analysis by considering fruit yield per plant as dependent variable on 16 other independent variables are presented in Tables 3 and 4, respectively discussed only at genotypic level. Among the 17 traits chosen for path analysis at genotypic level viz., plant height at 90 DAT (0.235) (Shende et al., 2014), leaf area at 90 DAT (0.228), days to first fruit maturity (0.162), number of fruits per cluster (0.280) (Muniappan et al., 2010, Karak et al., 2012, Arunkumar et al., 2013, Nayak and Nagre, 2013, Shende et al., 2014 and Patel et al., 2015) and early yield per plant (1.903) (Arunkumar et al., 2013 and Nayak and Nagre, 2013) had positive direct effect indicating their true positive and significant association with yield per plant.

\section{Conclusion}

The results of character association studies revealed that the total yield per plant had significantly and positive association with plant height, plant spread, number of primary branches and stem girth all at 90 DAT along with early yield per plant, number of fruits per plant and fruit diameter. Whereas, days to first flowering, days to 50 per cent flowering and days to first fruit maturity both at genotypic and phenotypic level was 


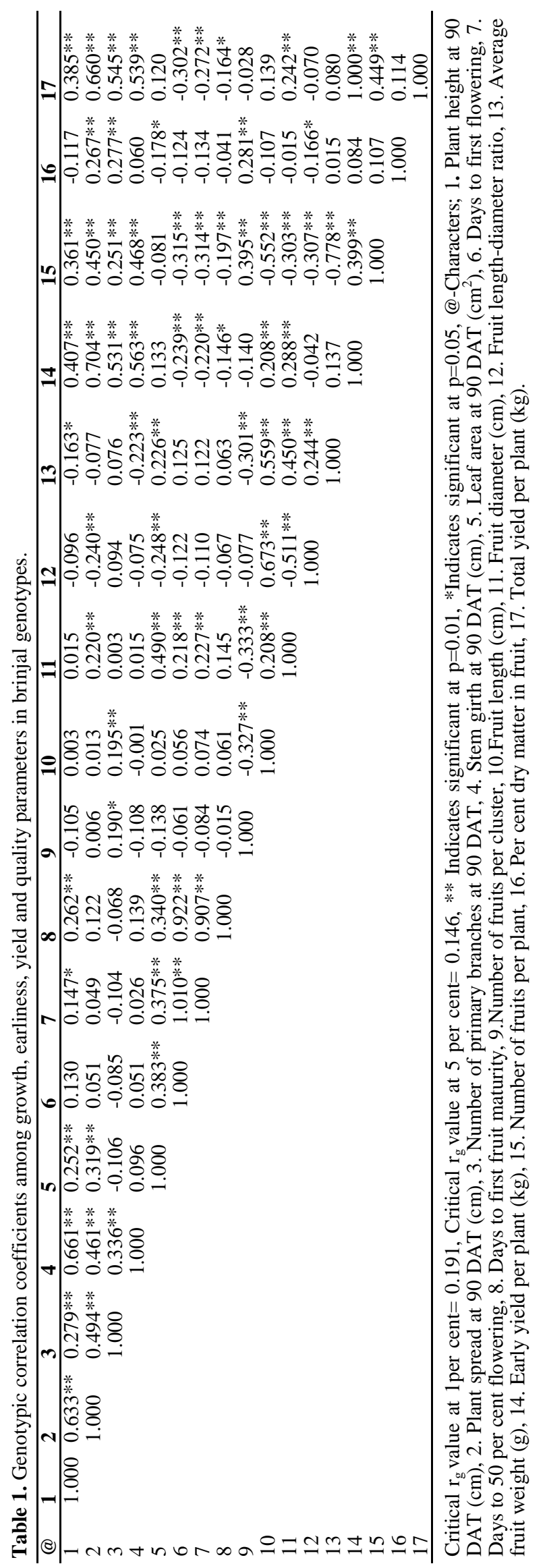

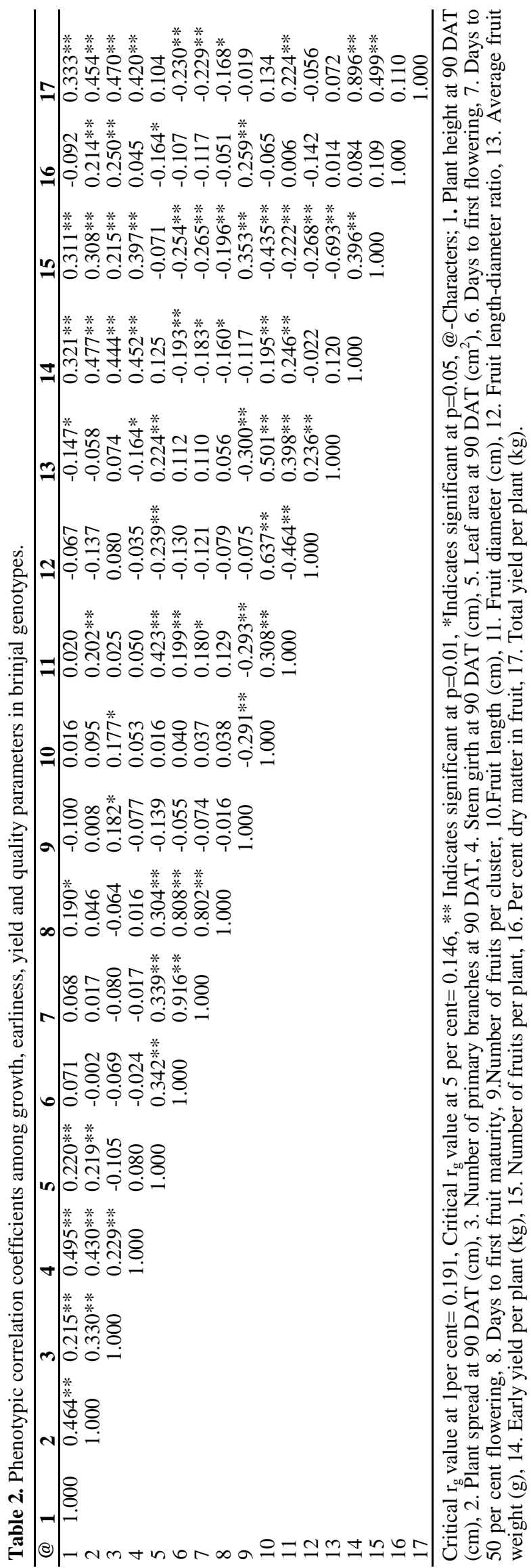




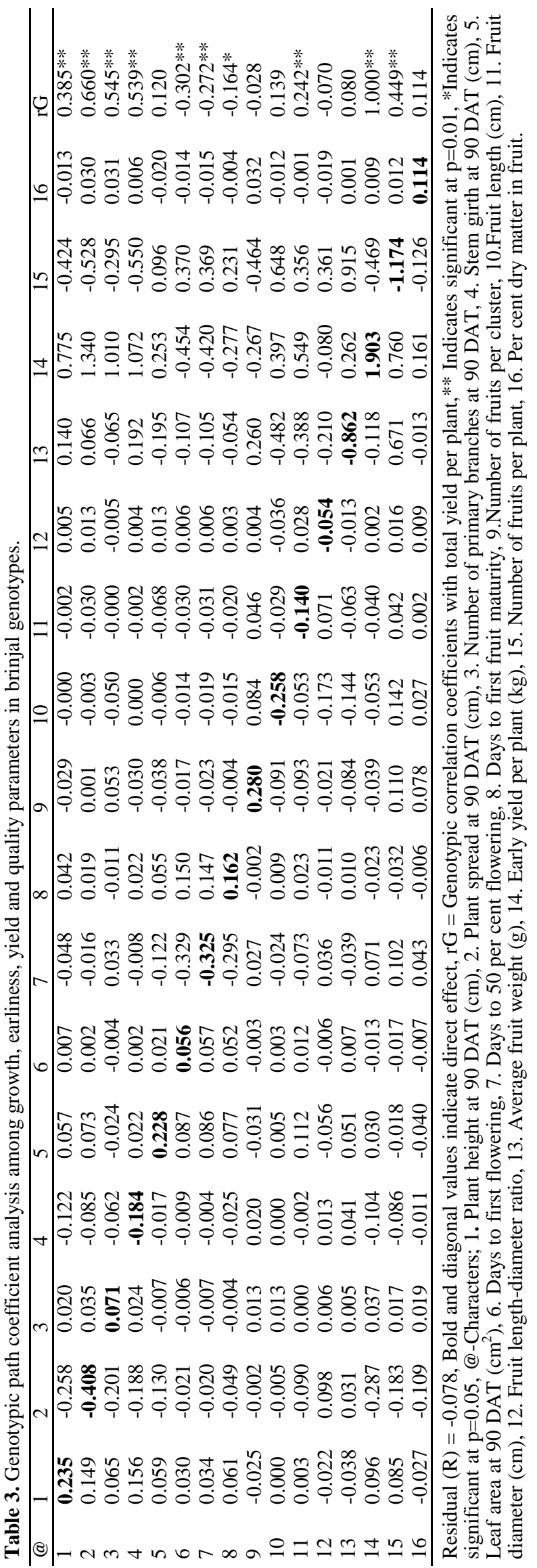

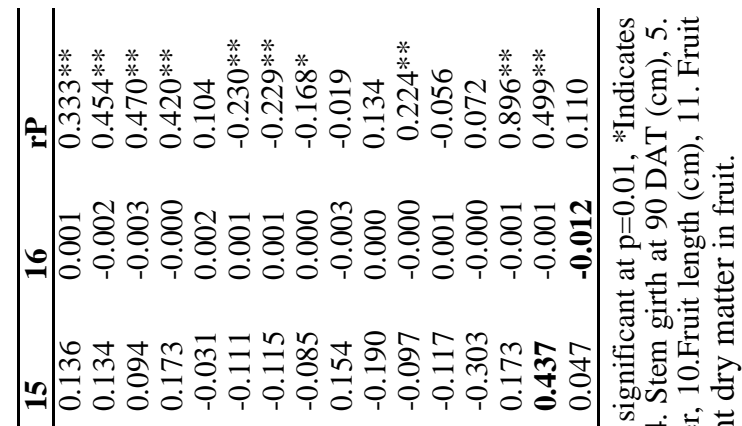

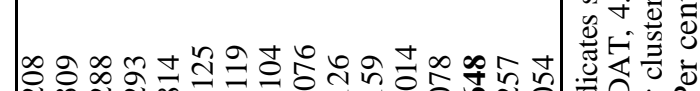

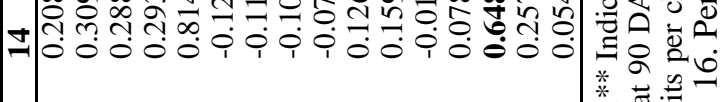

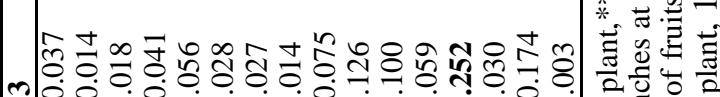
2 .

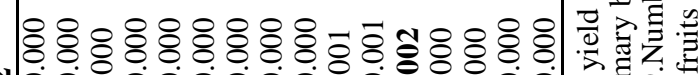
I

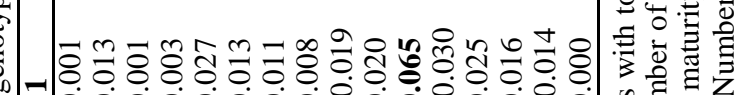

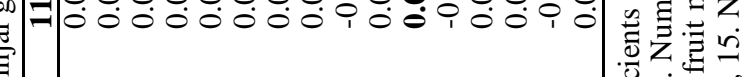

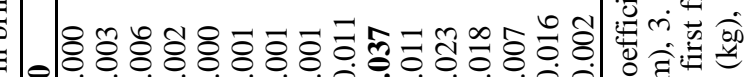

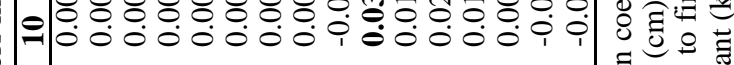

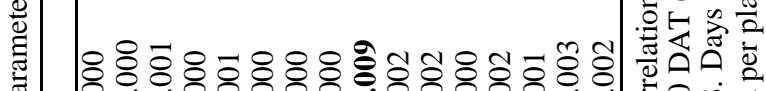
a -

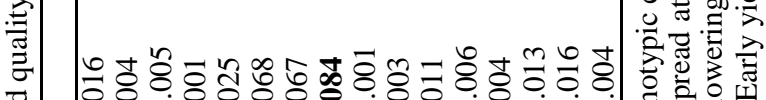

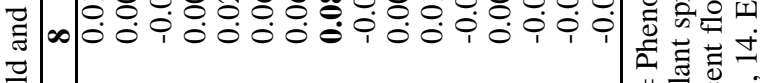
留

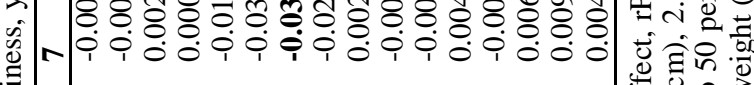
ब

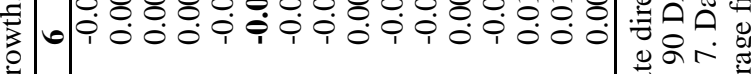

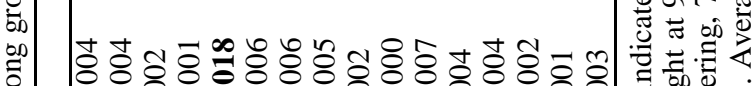
m

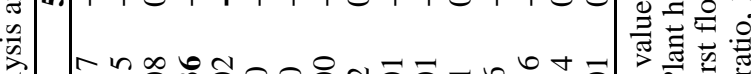

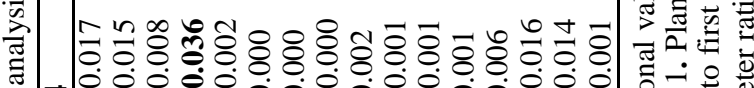
- $\rightarrow$ i i i 包

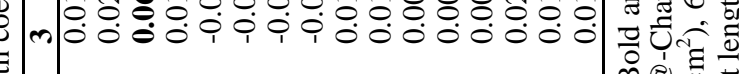
壳

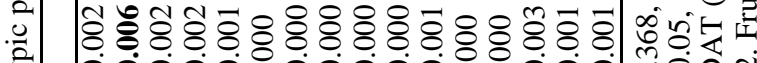
繁 N 离

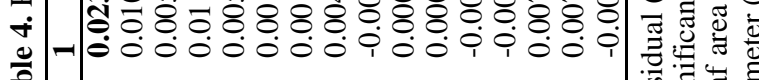
死| 
significant and negatively associated. Narrow differences between the genotypic and phenotypic correlation coefficients were observed for various traits in the present findings and this indicates the lesser influence of the environment in the expression of these traits and presence of strong inherent association among the traits. Path analysis studies revealed that plant height $(0.235)$ and leaf area $(0.228)$ both at 90 DAT, days to first fruit maturity (0.162), number of fruits per cluster (0.280) and early yield per plant (1.903) had exhibited significantly positive association with direct effect on yield per plant at genotypic level. The direct selection for these traits would be rewarding for improvement in the total yield per plant.

\section{REFERENCES}

Al-Jibourie, H. A., Miller, P. A. and Robinson, H. F. (1958). Genotypic and environmental variance in an upland cotton cross of interspecific origin. Agronomy Journal, 50:633-637

Anonymous (2012). Improved Cultivation Practices of Horticulture Crops (Kannada). University of Agricultural Sciences, Dharawad, pp. 173-183.

Arunkumar, B., Kumar, S. V. S. and Prakash, C. G. (2013). Genetic variability and divergence studies in brinjal (Solanum melongena L.). Bioinfolet, 10(2B):739-744.

Dahatonde, K., Dod, V. N., Nagare, P. K. and Wag A. P. (2010). Correlation and path analysis studies in purple fruited brinjal (Solanum melongena L.). Asian J. Hort., 5 (2):428-430

Dewey, D. R. and Lu, K. H. (1957). A correlation and path coefficient analysis of components of wheat grass seed production. Agron. J., 51:515-518

Grafius, J. E. (1959). Correlation and path analysis in barley. Agron. J., 51:551-554

Hung, H.C., Joshipura, K.J., Jiang, R., Hu, F.B., Hunter, D. and Smith-Warner, S.A. (2004). Fruit and vegetable intake and risk of major chronic disease. J. Nat. Cancer Inst., 96:1577-1584

Kalloo, G. (1994). Vegetable Breeding, Panima Educational Book Agency, New Delhi.

Kalpana, D., Dod, V. N., Nagre, P.K. and Wag, A.P. (2010). Correlation and path analysis studies in purple fruited brinjal. The Asian J. Hort. 5 (2):428-430

Karak, C., Ray, U., Akhtar, S., Naik, A. and Hazra, P. (2012). Genetic variation and character association in fruit yield components and quality characters in brinjal [Solanum melongena L.]. J. Crop and Weed, 8(1):86-89

Muniappan, S., Saravanan, K. and Ramya, B. (2010). Studies on genetic divergence and variability for certain economic characters in eggplant (Solanum melongena L.). Electronic J. Plant Breed., 1 (4):462-465

Nayak, B. R. and Nagre, P. K. (2013). Genetic variability and correlation studies in brinjal (Solanum melongena L.). Int. j. appl. and pharmaceutical tech., 4(4):212-215

Patel, K., Patel, N.B., Patel, A.I., Rathod, H. and Patel, D. (2015). Study of variability, correlation and path analysis in brinjal (Solanum melongena L.). The bioscan, 10 (4):2037-2042

Shende, R.A., Desai, S.S. and Dalvi1, V.V. (2014). Character association and path analysis in brinjal (Solanum melongena L.). Int. J. Agri. Sci., 10 (2):631-633

Shipley, B. (2000). Cause and Correlation in Biology: A User's Guide to Path Analysis, Structural Equations and Causal Inference Cambridge University Press.

Singh, A.P., Luthria, D., Wilson, T., Vorsa, N., Singh, V., Banuelos, G.S. and Pasakdee, S., (2009). Polyphenols content and antioxidant capacity of eggplant pulp. Food Chem., 114:955-961

Thangamani, C. and Jansirani, P. (2012). Correlation and path analysis studies on yield attributing characters in brinjal (Solanum melongena L.). Electronic J. Pl. Breed., 3(3):939-944

Wright, S. (1921). Correlation and causation. J. Agric. Res., 20:557-587 